DOI 10.38129/Ann.Yur.Ist.2019.3.1.2.65

УДК 340.132 .233

\title{
БОРЬБА ВИЗАНТИИ ЗА ПРАВО ВЛАДЕНИЯ ИТАЛИЕЙ: ИСТОРИКО-ЮРИДИЧЕСКАЯ ХАРАКТЕРИСТИКА ВОЙНЫ 541-552 ГГ.
}

\author{
ВИКТОР МЕЛЬНИК (Киев, Украина)*
}

Более четырех лет (535-540 гг.) понадобилось византийским войскам на установление полного контроля над Далмацией, Сицилией и большей частью Италии. В 537 г. была издана специальная новелла Юстиниана о переходе Сицилии под непосредственное управление имперских чиновников ${ }^{1}$. Эта новелла содержала нормы, характерные для многих новелл Юстиниана, изданных после републикации Кодекса (534). Вопервых, административные единицы Восточной Римской империи существенно расширялись. Теперь две провинции могли управляться лишь одним правительственным чиновником. Кроме того, произошла существенная унификация региональных форм самоуправления. Вводились новые полномочия для должностей претора, ректора и проконсула. Правители провинций были обязаны руководить как военными, так и гражданскими структурами. Этим шагом Юстиниан положил конец военно-административной структуре императора Диоклетиана (284-305), разработавшего систему полевых армий (comitatenses).

Восточная Римская империя возвращалась к тактике пограничной защиты (линия limes) и гарнизонного отпора (castellis) по всей линии границы. В первую очередь это касалось персидской и балканской границ. Увеличение числа славянских набегов, вместе с ожесточенными войнами на восточных азиатских территориях, вынудили Юстиниана осознать губительность применения только больших военных соединений. Славяне в 530-х гг. захватывали территории на Балканах, подобно германцам, прорвавшимся в Западную Римскую империю 31 декабря 406 г. (вандалы, бургунды, свевы). Поэтому Юстиниан решил вернуться к старой римской военной системе, испытанной в эпоху принципата (27 г. до н. э. - 284 г. н. э.) и модернизированной в контексте географического применения и политического значения.

${ }^{1}$ Nov. Just., $75 ; 104$. 
Правители провинций обязаны были мобилизовать достаточные силы для обороны регионов и отвечали головой перед императором за варварские и персидские набеги. Перед ними стояла задача координировать действия с высшим командованием и оборонять каждый византийский населенный пункт. Кроме того, прокураторы должны были постоянно следить за сохранением достаточного уровня коммуникации между отдаленными частями вверенных регионов ${ }^{2}$. Что интересно, большое расширение полномочий совершенно не превращало региональных наместников в самовластных диктаторов. Юстиниану удалось наладить распределение постов так, чтобы сохранять перманентный контроль над каждым чиновником ${ }^{3}$. Юстиниан в своих новеллах прямо заявлял, что перед центральной властью стоит задача обезопасить коммуникацию внутри имперских регионов от различных проявлений сепаратизма и диктаторских притязаний наместников ${ }^{4}$

Сицилию Велизарий подчинил непосредственной власти Юстиниана во второй половине 535 г. Но упомянутая законодательная новелла 537 г. ${ }^{5}$ не распространяла на Сицилии новый имперский административный порядок в полной мере. Новелла косвенно упоминала о создании административных условий, но, в силу сравнительной близости театра военных действий, разграничивала военную и гражданскую власть. Во главе гражданской власти на Сицилии становился претор, который вначале подчинился квестору священного дворца, а потом был переведен Юстинианом под управление префекта претория Италии (Фиделия, Репарата и пр.). В обязанности претора входил контроль над судебными и исполнительными органами, назначение чиновников, сбор и транспортировка налогов, инвентаризация имущества сицилийцев, учет и выплата жалования. При этом, претор Сицилии не имел права командовать военными. Полная юрисдикция (судебная, исполнительная и т. д.) над военными, находилась в руках дукса - dux Siciliae. Власть претора и дукса, таким образом, была полностью разделена, чего к 537 г. не наблюдалось на территориях главных провинций Восточной Римской империи - Малой Азии, Балкан, Ближнего Востока. 3. В. Удальцова отмечает, что похожие административно-правовые послабления действовали лишь только в

\footnotetext{
2 Именно нарушение коммуникации (информационного и культурного обмена, политической координации) привело к самоуничтожению институтов императорской власти на территории Западной Римской империи в V в.

3 Об этом: Nov. Just., 24-26; 30; 39.

${ }^{4}$ Nov. Just., 25; 28; 30.

${ }^{5}$ Nov. Just., 75.
} 
Армении, «где была сильна местная знать и византийское правительство опасалось вводить строгую централизацию» ${ }^{6}$. 75-я новелла Юстиниана подчеркивала права и свободы старой римской аристократии Сицилии. Помимо Сицилии и Армении, определенные локальные особенности административных отношений (хотя и неощутимые политически) сохранялись в Египте. И Сицилия, и Египет именовались в новеллах nostrum quodammodo peculium, то есть личным имуществом императора.

Итак, граница, проходившая вдоль реки По, позволяет утверждать, что практически весь Апеннинский полуостров в мае 540 г. оказался под фактическим контролем Восточной Римской империи. Лишь небольшая часть северной территории между Павией и Вероной осталась под властью разрозненных и разгромленных остготских военных формирований. Вслед за административной реформой на Сицилии, система власти на территории Апеннинского полуострова с 536 года также была разграничена. Если до 535 г., король остготов и наместник Италии (Теодорих Великий 8 493-526 г2., Аталарих в 526-534 г2., Амаласунта в 534-535 г2.) был лицом, в руках которого, волею византийского императора, сосредоточивалась $u$ гражданская, и военная власть, то после начала боевых действий летом 535 г. Империя взяла курс на дуализацию системы властных полномочий в Италии.

В 536 г. Юстиниан назначил Фиделия префектом претория Италии. Он должен был осуществлять всю гражданскую власть. Военные полномочия находились в руках командующего имперской армией Велизария. Такой порядок сохранялся все последующие годы византийского владычества в Италии (536-572 гг.). Институт должности префекта претория функционировал отдельно от должности командующего полевой армией.

Среди функций префекта претория Италии (в 539 г. им стал грек Афанасий), важнейшей обязанностью было распространение и опубликование старых и новых законов (leges) императора Юстиниана Великого. 3. В. Удальцова отмечает: «Новеллы Юстиниана, изданные между 537 и 540 гг., а также наиболее важные эдикты византийского правительства, обнародованные ранее, не только доводились до сведения жителей этих областей (о чем есть прямые упоминания в самих новеллах и в Прагматической санкции 554 г.), но и становились там действующим

\footnotetext{
${ }^{6}$ Удальиова 3. В. Италия и Византия в VI веке. / 3. В. Удальцова. - М.: АН СССР, 1959. - c. 322.
} 
правом» 7 .

Интересно, что Прагматическая санкция говорит о давнем использовании византийского законодательства в Италии. В одиннадцатом пункте этого императорского документа сказано: «Сверх того мы постановляем, чтобы соблюдались право и законы, содержашиеся $b$ нашем кодексе, которые мы уже давно послали в Италию в виде отдельных эдиктов»8. В данном контексте полезно вспомнить об указах Юстиниана Великого, издававшихся для Италии и западных римлян в 534-535 гг. Наверняка, существовали также более ранние распоряжения византийских императоров относительно полномочий и функций итальянских наместников. Это не вызывает никаких сомнений, если принять во внимание юридическую принадлежность позднеантичной Италии к Восточной Римской империи (после событий 476-480 гг.). К моменту издания императором Юстинианом Прагматической санкции для Италии (554 г.), обозначавшей юридическое окончание второй итальянской кампании, Апеннинский полуостров де-юре находился под контролем Константинополя 74 года (480-554 гг.) $)^{9}$

Предполагаем, что издание Эдикта Аmaлариха Амаласунтой в 534 г. являлось реакцией на общую законотворческую тенденцию в Восточной Римской империи. В любом случае, практическое введение кодифицированных норм римского права на итальянской территории, осуществлялось постепенно, поскольку Юстиниан существенно ослабил давление закона на рабов, которые больше не выполняли главные экономические функции. Теперь первую скрипку в социальноэкономическом оркестре Империи играли колоны - полузависимые крестьяне, юридически прикрепленные к определенному земельному наделу. На Сицилии и значительной части Италии, в отличие от Малой Азии и Балкан, значение рабского труда оставалось высоким. Армения, Египет и Сицилия оставались рабовладельческими провинциями, что

7 Удальияова 3. В. Там же. - с. 323.

8 Pragm. Sanc., 11. Перевод 3. В. Удальцовой: Удальцјова 3. В. Там же. - с. 323. Курсив наш!

9 О широком распространении норм кодифицированного римского права в Италии (536-540 гг.) см. в законодательных новеллах того времени: Nov. Just., 69; 70; 73; 75; 80; 89; 91; 101; 104; 106. Интересен спор о хронологии окончательного распространения всех норм Дигест, Институций и Кодекса на итальянскую провинцию. В любом случае, не вызывает сомнений полноценное использование итальянцами систематизированного Юстинианом законодательства. Об этом детально в: Удальцова 3. В. Там же. - с. 323, особенно - с. 323, прим. 5! 
вынуждало Юстиниана идти на определенные административные хитрости. Разделение гражданской и военной властей являлось одной из таких хитростей. Также Юстиниан не назначал греков в первые годы войны на важнейшие гражданские должности (хотя греки полностью руководили военными подразделениями). В случае с префектами претория Фиделием и Репаратом, Юстиниан вел политическую игру с итальянскими рабовладельцами-аристократами, благодаря чему снискал еще большую поддержку зажиточных апеннинских провинциалов. Назначение грека Афанасия префектом претория в 539 г. прервало сложившуюся было традицию и гражданская администрация постепенно подчинилась выходцам из Нового Рима - Константинополя. В данном случае Юстиниан вел себя политически верно и занимался окончательной ликвидацией последствий итальянского сепаратизма, подогревавшегося самостоятельной внутренней политикой остготских королей-наместников.

Впрочем, майское соглашение 540 г., прекратившее период остготского владычества в Италии, не остановило разрастания германских амбиций. Ряды воинственных остготских земледельцев, живших в северных горных районах Италии, были пополнены изгнанными из Равенны воинами ${ }^{10}$. В городе Павия (Тичин), в июне 540 г. собрался большой военный совет ocmготов ${ }^{11}$. Германцы решили избрать вождя по старому обычаю - на тот момент представители королевского рода Амалов либо погибли, либо перешли на сторону Восточной Римской империи. На этом совете собравшиеся остготы заявили, что «опасности войны они предпочитают состоянию рабства».

Сначала титул вождя предложили руководителю миланской группировки остготов Урайе, но тот отказался в пользу племянника вестготского короля Теудиса - Ильдибада (540-541) ${ }^{12}$.

Как мы помним, вестгот Теудис был представителем чиновнической номенклатуры времен Теодориха Великого (493-526). Происходя из знатного остготского рода Паннонии, он длительное время являлся оруженосцем самого Теодориха. Именно Теудис «опекал» внука Теодориха Амалариха и контролировал испанские дела. Когда дело приближалось к распаду государства Теодориха, Теудис совершил первый и главный шаг организовал коронацию Амалариха вестготским королем. Сразу же после

\footnotetext{
10 Procop. BG, II.30.3; Iord. Rom., 378.

11 Procop. BG, II.30.3-5.

12 Procop. BG, II.30.14-16.
} 
смерти Амалариха13, Теудис занял его престол, будучи политическим основателем Толедского королевства вестготов ${ }^{14}$. Поражение вестготов в 507 г. от франков и бургундов, потеря своей главной территории (Аквитании) и длительное подчинение Равенне (511-526 гг.) значительно ограничили вестготские силы, но правление Теудиса (531-548) подняло боевой дух вестготов и создало надежды на восстановление политического могущества старой Вестготии. Вполне очевидно, что Теудис был главным лоббистом возвышения Ильдибада. Теперь, после многих лет подчинения вестготов остготам, все могло перевернуться наоборот. Известно, что Теудис был человеком амбициозным и честолюбивым. Объединив усилия с остатками остготов (самыми воинственными остатками!) Теудис мог предпринять попытку реставрации могущественного королевства Теодориха Великого. Вот только первенство в реставрированном королевстве должны были получить вестготы, а не остготы. Кроме того, в территориальном контексте, Теудиса, по понятным причинам, больше интересовали Аквитания и Южная Галлия, утраченные готами под нажимом франков.

По сообщению комита Марцеллина (Marcellinus Comes), Ильдибад был избран остготским рексом - королем, но реальная власть в североитальянской Остготии осуществлялась им вместе с генералом Урайей ${ }^{15}$. Считаем вполне реальной гипотезу о том, что Урайя мог быть приставлен остготской знатью к продвигаемому Теудисом (531-548) кандидату Ильдибаду ради обеспечения внешнеполитической безопасности. Впрочем, как отмечал Прокопий, если Урайя вел роскошный (по остготским меркам) образ жизни, то Ильдибад «жил бедно, не прикасаясь к королевским деньгам»16. Вызывая своим сдержанным поведением общественное одобрение и обладая только одной тысячей воинов, Ильдибад начал восстановление остготской власти над северной Италией. Сначала он принялся за наведение порядка среди самих остготов. Разрозненные и зараженные анархией отряды вынуждались к подчинению17.

После боя под Тревизо, когда Ильдибаду удалось разбить иллирийские и герульские части византийского полководца Виталия,

13 Амаларих пробыл вестготским королем всего 5 лет - с 526 по 531 гг. Его убили на юге Галлии франкские солдаты во время грабительского набега на вестготскую провинцию Нарбонну.

14 Теудис правил Испанской Вестготией с 531 по 548 гг.

${ }^{15}$ Marc. Chron., a. 540.

16 Procop. BG, III.1.39.

17 Procop. BG, III.1.27. 
остготы окончательно возвратили под свой контроль регионы Лигурии и Венеции. Иордан и Прокопий отмечали, что победа под Тревизо принесла новому королю большую славу ${ }^{18}$. Сплочение разрозненных сил остготов вокруг фигуры вестготского ставленника Ильдибада раздражало многих представителей остготской знати. В первую очередь, сожалел о собственном отказе от короны Урайя. Конфликт с Ильдибадом был неизбежен и вскоре Урайя был убит ${ }^{19}$. Но не вызывает сомнений, что круг противников Ильдибада оказался слишком широким, а политический вес короля слишком маленьким для противостояния старой остготской военной знати. В мае 541 года король Ильдибад погиб от меча собственного телохранителя Веласа $^{20}$.

Ликвидация Ильдибада вновь внесла раздор в остготские общины. Кроме того, она нивелировала возможное военное сотрудничество с вестготами. Внутри остготских общин возросло влияние других германских племен, сражавшихся когда-то вместе с остготами в Паннонии и Далмации ${ }^{21}$. Племя ругов сумело протолкнуть на властные вершины своего ставленника - Эрариха, ставшего королем остготов после смерти Ильдибада ${ }^{22}$.

Североитальянское наступление Ильдибада (540-541) пришлось непосредственно на времена отражения персидской угрозы Юстинианом Великим в Месопотамии и Сирии. Усилия всех имперских чиновников Константинополя были обращены к Антиохии и заключению мирного договора. В связи с этим Юстиниан даже отменил триумфальное чествование победителя остготов Велизария (540), которое должно было состоятся по древнему римскому обычаю.

Учитывая гениальные административные и юридические таланты Юстиниана, удивительным кажется тот факт, что византийские войска Италии, после немедленного перевода Велизария на персидский фронт (540 г.), перешли под совместное управление трех полководцев. Генералы Бесса, Иоанн и Константин постоянно ссорились друг с другом, что негативно сказывалось на организации управленческой системы в регионе. Военная администрация византийцев дублировала полномочия местных органов власти. К слову, бюрократов всегда хватало в Италии. Особый расцвет апеннинской бюрократии начался со времен установления

18 Procop. BG, III.1.34-36; Iord. Rom., 378.

19 Procop. BG, III.1.37-42.

20 Procop. BG, III.1.43-49.

${ }^{21}$ Procop. BG, III.2.5.

22 Procop. BG, III.2.1-4. 
Диоклетианом (284-305) политического режима домината (dominatus). Римские сенаторы-рабовладельцы не желали делиться своей властью с греческими эмиссарами. Большое значение, на наш взгляд, имели также социальные различия $b$ процессе экономического производства. Если для греков нормой было преимущественное использование колонов, то в Италии оставался прежним жесткий режим рабовладения. Поддающееся мощному моральноэтическому влиянию христианства, римское право пыталось сгладить отношения между господами и рабами, но длительное управление остготов-ариан серьезно затруднило процесс перехода Италии на уровень преимущественного использования труда полузависимых и полностью независимых крестьян.

В аристократических усадьбах римлян периода остготского владычества, произошла определенная консервация обычаев. (Не в последнюю очередь, из-за слабой торгово-экономической коммуникации между Италией и Элладой в 468-535 гг.)23. И теперь, когда перед присланными вместе с префектом претория Афанасием византийскими чиновниками, была поставлена задача восстановить и укрепить итальянскую экономику (ради создания здесь мощной налоговой базы Империи), в открытой оппозиции к чиновникам оказались многие сенаторы и аристократы. Получалось так: остготские короли раньще не вмешивались во взаимоотношения аристократов и зависимого от них населения, тогда как византийский император начал проводить социально-экономические преобразования. И хотя цель этих преобразований состояла в укреплении налогового потенциала Италии, косвенно они направлялись в сторону изменения социального фундамента производства. Возникли первые внутренние трения между чиновниками Константинополя и аристократами Италии.

Впрочем, трения подобного рода, в условиях трансформации социально-экономической системы (и, соответственно, культурной ломки мировоззрения) могли возникнуть (и постоянно возникали) в любой другой провинции. Их нельзя возводить в ранг фундаментального

23 В 468 г. армия византийского императора Льва I Великого (457-474), руководимая шурином императора Василиском, потерпела сокрушительное поражение от вандало-аланского войска короля Гензериха (428-477). Решающая схватка под Карфагеном лишила Италию и всю Западную Римскую империю контроля над морскими путями сообщений в Средиземноморье, а Византии пришлось оборонять уже собственный Эгейский бассейн. Данное событие вызвало политическое падение Западной Римской империи в 476-480 гг. и привело к остановке полноценной средиземноморской торговли. 
«цивилизационного» противоречия греков (условного «Востока») и римлян (условного «Запада»). Необходимо особо подчеркнуть: идеологических противостояний между итальянцами и греками в то время не существовало вообще. Некоторые признаки политического недовольства выросли из возвышения центральной администрации. Упомянутая же тройка полководцев (Бесса, Иоанн и Константин) назначала на все ключевые посты выходцев из Константинополя. Уже к началу 541 г. такой подход начал вызывать политическое недовольство, подогреваемое прямой зависимостью крестьян от сенаторов-аристократов. Недовольными на самом деле были представители высших слоев общества, принимавшие все возможные меры для запугивания византийских чиновников (в том числе, путем воздействия на подконтрольные народные массы). Итальянская аристократия впервые за много лет почувствовала возможность не политического, но экономического притеснения своих прав. Это следует связывать с фискальной политикой новых греческих чиновников. Именно налоговое законодательство Юстиниана (административная централизация, пропаганда христианских принципов взаимоотношений в производстве, попытка создания налоговой базы при раздельном функционировании военных и гражданских структур) сыграло злую шутку, сведя в итоге на нет все достижения первой итальянской кампании Велизария (535-540).

Так как исторический процесс представляет собою неразрывную связь причин и следствий, то ююбое рассматриваемое нами событие одновременно есть результатом предыдущего события и началом последующего. Вполне закономерно, что так случилось и с практикой сбора налогов византийскими логофетами геникона (налоговыми чиновниками). Юстиниан Великий, занимаясь кодификацией римского законодательства, руководствовался той огромной пользой, которую эта кодификация принесет для государственного устройства будущей единой империи, включающей провинции Востока и Запада. Помимо христианской религиозности и административной централизации, которые Юстиниан пытался учреждать по всей территории Византийской империи, существовал также и человеческий фактор - тот самый фактор исторического процесса, который погубил Урайю и Ильдибада на севере Италии. Ведь организация создания налоговых баз была устроена таким образом, что логофеты геникона получали заработную плату из государственной казны лишь согласно результату исполненной работы. Чем большая сумма собранных налогов указывалась логофетом геникона в отчетной документации, тем больше жалования ему выплачивал император. Находясь вдали от Константинополя, налоговики, работая в 
тесной связи с военной и гражданской администрацией, осознавали, что в виду военного положения на Апеннинском полуострове, шансов быть привлеченными по судебному обвинению у них намного меньше. Сформировался феномен, который вполне можно назвать «налоговым фронтом» итальянских военных кампаний Юстиниана. Опустошенные четырехлетними боевыми действиями территории опустошались вдобавок налоговыми чиновниками, которые усердно старались ради повышенного жалования. Особенно серьезно повлияло на рост всевозможных налогов византийско-персидский перемирие. И хотя бремя выплаты огромных сумм дани для персидского императора лежало на всех гражданах империи, для жителей Италии, всячески подстрекаемых недовольными сенаторами и землевладельцами, ломка старых порядков и создание новых казались неприемлемыми. Преследуя исключительно личные интересы, желая обогащаться всем чем только возможно, социальная верхушка Италии, сама не осознавая возможных политических последствий, разжигала антигреческие настроения.

Наследник Ильдибада Эрарих, происходивший из знатного рода племени ругов осевших на землях современной Венетии, правил остготами всего пять месяцев. Его убили в том же году (осенью 541 г.) 24. Однако, фигура краткосрочного правителя интересна для нас другими фактами.

Остготский король Эрарих был коронован ориентировочно в маеиюне 541 г. В то же время он выслал германское посольство в Константинополь, официально предложив Юстиниану признание существующих границ со стороны остготов. Последние должны были оставаться в пределах территорий за рекою По. При этом, речь шла об окончательном признании юридического верховенства восточного императора, но Остготское королевство должно было получить больще внутренней политической самостоятельности. Вполне возможно, что Эрарих ожидал военной помощи со стороны византийцев для укрепления собственной власти.

Основания для такого предложения у Эрариха были весомые. Война против итальянского контингента византийцев уже активизировалась и нарастала с каждым днем. Византийские пограничные заставы на реке По постепенно переходили к оборонительным военным мероприятиям. Мобилизованные королями Ильдибадом (540-541) и Эрарихом (541) отряды предпринимали постоянные набеги на укрепленные линии византийцев. Очень может быть, что военные нападения на императорские силы, в тот

\footnotetext{
24 Procop. BG, III.2.18.
} 
момент, воспринимались остготами не как возможность нанести византийцам поражение, но как реальная возможность вынудить императора помочь остготам в деле обустройства собственного королевства на Севере Италии. Этот тезис вполне подтверждает сообщение Прокопия, что Эрарих тайно предлагал Юстиниану передать Империи всю Северную Италию, за что он просил большую сумму денег и титул патриция 25 . Прокопий прямо указывает на то, что остготы подняли мятеж, узнав о тайных переговорах Эрариха с Восточной Римской империей.

Посольская миссия короля Эрариха (541) и возможность мирного установления византийского политического контроля над Северной Италией провалились не только из-за смерти самого Эрариха... В начале 542 г. Юстиниан заболел бубонной чумой. Эпидемия распространилась на большие территории, а Константинополь превратился в ее эпицентр. Уровень смертности был очень высокий. Император несколько месяцев находился без сознания. Его выхаживала лично императрица Феодора. Несмотря на все негативные прогнозы константинопольских врачей, Юстиниан выздоровел к середине 543 г. Это время болезни императора стало решающим для той кампании, которую мы назовем bmорой итальянской войной (541-552).

Осенью 541 г. королем остготов стал племянник Ильдибада - Тотила (541-552). Тотила организовал убийство Эрариха, хотя незадолго до этого лично вел переговоры с византийцами о передаче им крепости Тревизо 26. Иордан отмечал, что в момент избрания Тотилы королем, ему не исполнилось даже тридцати лет ${ }^{27}$. Комит Марцеллин в описании 542 года говорит о том, что предоставление остготами Тотиле королевской власти стало невероятным бедствием для Италии ${ }^{28}$. Так или иначе, но Тотила является одним из немногих варварских королей, который благодаря военному конфликту с великой Империей и соответственному вниманию источников, превратился в яркий и характерный образ позднеантичной/раннесредневековой эпохи. Большинство историков и биографов благоволят Тотиле и относятся к нему как к борцу за освобождение Италии и за политическую институционализацию остготов. Он был воином, но борцом не был. Нужно учитывать, что Тотила воевал не за Италию, а против Италии. Ведь Тотила противостоял Империи,

\footnotetext{
25 Procop. BG, III.2.15-18.

${ }^{26}$ Marc. Chron., a. 542.

27 Iord. Rom., 379.

28 Marc. Chron., a. 542.
} 
органической и законной частью которой Италия являлась всегда. При этом, Тотила явно пытался завоевать эту провинцию, отторгнуть ее от Империи (чего не сделал и никогда не пытался сделать Теодорих Великий).

Тотила искусно пользовался недовольством многих римских аристократов византийской налоговой политикой, привлекал на свою сторону разагитированные общественные низы. Интересным феноменом являлось широкое привлечение Тотилой на свою сторону итальянских рабов, что послужило причиной положительного восприятия Тотилы даже советской историографией. Его фигура удивительным образом сплотила в похожих позитивных оценках и ярких красках немецких историков-националистов, историков-германистов всего мира, итальянских, англосаксонских ученых и даже советских ученых-марксистов. Если Юстиниан открыто именуется «истинным антигероем» 29 , то Тотила называется «отважным героем» 30.

Для советской марксистской историографии характерно приписывание Тотиле определенной социальной направленности ${ }^{31}$. Безусловно, что классовая политика Тотилы была революционна для поздней античности (в этом мы полностью соглашаемся с 3. В. Удальцовой). Но, понимая ход исторических событий, учитывая реальную и законную принадлежность Италии к сфере влияния и административного контроля Византии, тяжело разделить проготскую позицию ученой. Вот как характеризует начало второй итальянской войны сама Удальцова: «В своей борьбе с империей остготская знать стремилась вернуть потерянные земли и богатства. Она не желала уступить римским рабовладельцам, вновь начинавшим хозяйничать в Италии, свои земельные владения, не хотела терять власть и влияние. Но в тоже время большая часть остготской знати не желала также и идти на серьезные уступки народным массам... Только страшное поражение, во многом обусловленное предательством самой же остготской знати, а также отсутствие поддержки со стороны народных масс Италии, заставило уцелевших вождей остготов серьезно призадуматься над дальнейшими судьбами своего племени. Сама логика борьбы с рабовладельческой империей, вновь протянувшей свои щупальцы к Италии, вынудила наиболее дальновидных из них пойти, как мы увидим

29 Хизер Питер. Восстановление Римской империи. Реформаторы Церкви и претенденты на власть. / Питер Хизер. - М.: Центрполиграф, 2015. - с. 144.

30 Балух В. О. Візантиністика. Курс лекцій. / В. О. Балух. - Чернівці: Книги-ХXI, 2006. - с. 86.

31 Ознакомившись с классической работой 3. В. Удальцовой, короля Тотилу неразборчивый читатель может счесть если не за социалиста, то, по крайней мере, за продолжателя дел Спартака. 
дальше, на временный союз с народными массами в расчете использовать в своих интересах широкое народное движение, развернувшееся вскоре в Италии. И наиболее талантливым вождем остготов, проводившим подобную политику, оказался Тотила. Именно он решительнее, чем другие, стремился обеспечить готам поддержку со стороны самых широких слоев населения Италии, и в этом секрет его успехов в борьбе с Византией. Но в этом же и причина ненависти к нему со стороны известной части знати»32.

Во-первых, остготская знать действительно боролась за возврат доходов и земель, за восстановление своего привилегированного положения на всей территории Италии (включая Далмацию и Сицилию). Но ведь римские «рабовладельцы» не «вновь начинали хозяйничать в Италии». Римские рабовладельцы более прибыльно и успешно хозяйничали в Италии во времена остготского владычества. Пятьдесят пять лет римские рабовладельцы, признавая юридическое верховенство императора, занимались политической кооперацией с германской верхушкой вообще и остготской верхушкой в частности. Римские рабовладельцы получили от остготов полную свободу действий - в том числе относительно эксплуатации рабов. Соответственно, римские рабовладельцы еще хуже «хозяйничали» в Италии на протяжении всего периода правления остготов, чем это было до того, во времена западноримских императоров эпохи домината.

Во-вторых, «логика борьбы остготов с рабовладельческой империей» не совсем адекватна канве исторических событий. Остготы сами участвовали в работорговле и никоим образом не могли выйти за рамки экономической системы поздней античности (или даже раннего средневековья). Мировоззрение остготов, как и любых других варваров, являлось полностью рабовладельческим. Никакого благосклонного отношения к рабам или зависимым людям, на протяжении сорокатрехлетнего правления остготов (493-536 гг.), в Италии не наблюдалось. Римские рабовладельцы полностью контролировали свои земли и рабов, а остготы подчинялись «рабовладельческой империи», называя себя верноподданными восточноримского императора ${ }^{33}$. Зачем рабовладельцам-остготам вообще было социально-экономически бороться с рабовладельческой империей? Тем более, после того как Империя санкционировала переход Италии под власть остготов (в 488 г.)! Остготы и византийцы были едиными во всех своих интересах на протяжении

\footnotetext{
32 Удальијова 3. В. Там же. - с. 336.

33 Iord. Get., 304.
} 
длительного времени. Юридический контроль Византии над Италией подтверждает это.

В-третьих, утверждение Удальцовой о том, что Византия «вновь протянула свои щупальцы к Италии» 34 не соответствует ходу исторических событий. Ведь сама 3. В. Удальцова обработала огромное количество материала, посвященного различным аспектам политико-юридической жизни остготской Италии... Ход истории и правовой материал позволяют сделать вывод о том, что с 480 г. Италия являлась подчиненной Византии территорией ${ }^{35}$. И Одоакр, и Теодорих, и Аталарих, и Амаласунта 36 были наместниками Восточной Римской империи ${ }^{37}$. Все имели разные политические отношения с Империей, но все принимали и признавали верховную власть императора. Как же могло произойти «протягивание щупалец» к Италии, если Италия была де-юре зависимой от Константинополя территорией? Кроме того, убийство Теодатом при поддержке остготской знати законной королевы-наместницы Амаласунты (535 г.) не добавляет сопротивлению остготов законности. То же самое очевидно и в отношении Матасунты (внучки Теодориха Великого), которая открыто выступала за Византийскую империю. То, что весь королевский род Амалов поддерживал византийцев позволяет утверждать, что германистический взгляд на остготско-византийские войны (присущий даже ведущим советским и современным отечественным специалистам) необходимо коренным образом пересмотреть.

34 Удальцова 3. В. Там же. - с. 336.

35 См. нашу попытку обощения этого тезиса: Мельник В. М. Римская империя в V веке. Крушение или перерождение? // Наука и техника. Июль, 2019. №7 (158). С. 60-66.

36 О королеве Амаласунте, как «стороннице» императора Юстиниана писал и Георгий Курбатов. См.: Курбатов Г. Л. Ранневизантийские портреты: К истории общественно-политической мысли. Ленинград: Издательство Ленинградского университета, 1991. С. 253. Для понимания юридической зависимости германских королей Италии от власти и персоны императора Восточной Римской империи полезна вся седьмая глава этой книги: Курбатов Г. Л. Там же. С. 221-266.

37 Ведущий украинский историк Василий Балух об этом пишет: «В 477 г. Одоакр формально подчинился константинопольскому императору и правил как назначенный Зеноном патриций и военачальник, хотя на самом деле стал первым германским военным правителем Империи. Итак, падение Западной империи внешне выглядело как восттановление единства всего государства, ијентр которого окончательно переместился на Восток». - Балух В. О. Історія античної цивілізації у трьох томах. Том 2: Стародавній Рим. Чернівці: Наші книги, 2016. С. 686. 
Король Тотила (541-552) действительно был незаурядной личностью, талантливым военным вождем и политиком. В истории готов (и остготов, и вестготов вместе) его личность должна занимать вторую позицию после Теодориха Великого. Заметим однако, что обеспечение «широкой поддержки народных масс» для начинаний Тотилы было бы невозможно, если бы не подстрекательство со стороны многих представителей римскоитальянской элиты и если бы не затяжная болезнь Юстиниана Великого, осложненная необходимостью решать персидскую проблему на восточной границе ${ }^{38}$. Грубо говоря, Юстиниан на некоторое время отвернулся от западных провинций, что было явной ошибкой.

Тотила начал активные боевые действия в 542 г., разбив византийцев под Вероной. Далее следовали победы возле Фаэнцы и уничтожение армии полководца Иоанна в окрестностях Флоренции (весна 542 г.). Победа возле Муджелло позволила Тотиле привлечь на свою сторону большое количество пленных византийцев ${ }^{39}$. Весна-лето 542 года были наиболее страшными для византийской армии. Количество готского войска многократно усилилось за счет итальянского плебса и многочисленных дезертиров из разваливающихся императорских подразделений. Зинаида Удальцова отмечает: «Весть о полном поражении столь прославленного полководца, как Иоанн, навела панический страх на византийских командиров, которые теперь совершенно отказались от наступательных действий против Тотилы и вся их деятельность сводилась лишь к укреплению занятых ими крепостей» ${ }^{40}$.

Летом 542 г. разросшаяся армия Тотилы вступила в Цезену, Урбин, Монс Феретр, Петру Пертузу. Переход Апеннин обеспечил остготов доступом к огромным запасам хлеба, сосредоточенным византийцами в провиниии Тусиия ${ }^{41}$. Прокопий Кесарийский отчетливо свидетельствует, что войска Тотилы встречали сопротивление у стен городов, но легко завоевывали сельские местности. К началу 543 г. король Тотила захватил Южную Италию Бруттий, Апулию, Луканию, Калабрию. В этих регионах проживало множество этнических греков и эллинизированных итальянцев. Они поддались на искусно организованную пропаганду остготов. Как отмечает Прокопий, Тотила приказал своим подчиненным относится к римлянам мягко. В остготской армии часто встречались случаи казни за плохое

\footnotetext{
38 Курбатов Г. Л. Там же. С. 253-254.

39 Procop. BG, III.5.19.

40 Удальцова З. В. Там же. - с. 339.

41 Iord. Rom., 379.
} 
отношение к римскому населению (и даже к военнопленным!) ${ }^{42}$. Его армия на первых порах проявила «так много человечности, что этого нельзя было ожидать ни со стороны врага, ни со стороны варвара» ${ }^{43}$. Вскоре византийцы вообще и греки в частности составляли порядочную долю войска Тотилы.

Тотила был видным политическим технологом. Его политический талант, хотя и проявлялся в решениях менышего масштаба, был очень близок к административному гению императора Юстиниана. Византийская кодификация римского права не принесла Константинополю психологического перевеса во второй итальянской войне (541-552 гг.), хотя, безусловно, влияла на ход событий первой кампании (536-540 гг.), будучи важнейшей составной частью «римской идеи». Однако в 541-543 гг. итальянцы почувствовали пресс имперской налоговой бюрократии и полный развал военной администрации. Большой бедой стали отряды византийских дезертиров. Тотила организовывал пропаганду, используя огромную и хорошо подготовленную сеть агитаторов. В Риме и Неаполе распространялись прокламации Тотилы, воздействовавшие на более образованные слои населения ${ }^{44}$. Константинополь явно терял контроль над ситуацией.

В «Диалогах»45 Папы Римского Григория I Великого (590-604) описывается популистский и демагогический подход Тотилы, который ни перед чем не останавливался в процессе обретения или осуществления власти. Папа Григорий чаще всего акцентировал на притеснениях ортодоксальных священников со стороны остготов. Именно в этих притеснениях папа видел реальную сущность внутренней политики остготского короля. Фактически, возврат многих итальянских территорий под контроль германцев означал установление новой и более жесткой еретической диктатуры ариан 46.

В 543 г. перед Тотилой стояла задача привлечения широких итальянских масс на сторону остготов. Это было связано с завоеванием Южной Италии, которая, как известно, наиболее симпатизировала

42 Procop. BG, III.6.4; 8.12-25; 8.1.

43 Procop. BG, III.8.1.

44 Попытка охарактеризовать социально-экономическую политику Тотилы: Удальцова 3. В. Там же. - с. 340-353; Левченко М. В. История Византии. / М. В. Левченко. - М.-Л., 1940. - с. 81-83.

45 В православной церковно-историографической традиции чаще употребляется неверный перевод «Двоеслов», который, однако, отражает философскую задумку трактата Папы Григория.

46 Greg. I. Dial., I.2; II.15, 31; III.11, 13, 18. 
Византии и являлась главным поставщуиком продовольствия для всего Апеннинского полуострова. В этом направлении король Тотила сделал важный и умелый политический шаг - уменьшил налогообложение для больших землевладений и фактически объявил о неприкосновенности всей сотрудничавшей с Константинополем сенаторской аристократии ${ }^{47}$. При этом, обеспечение безопасности сенаторов и сохранение их главных доходов перекрывалось огромными конфискациями церковного имущества.

Получалось так: остготы грабили церкви и разоряли монастыри, а римские сенаторы спокойно смотрели на бесчинства ариан и тихо поддерживали их победное шествие, изменяя религии ради налоговых льгот. К примеру, папа Григорий (590-604) писал в «Диалогах», что остготы ограбили Фунденский монастырь в провинции Самний, что, к его удивлению, не вызвало никаких неудовольствий со стороны местных аристократов ${ }^{48}$. Здесь считаем необходимым подчеркнуть, что именно начальные успехи Тотилы и безнаказанный захват Южной Италии привели впоследствии к организации масштабных гонений на сенаторскую аристократию. В итоге, воспользовавшись общественным недовольством высоким византийским налогообложением, захватив большую часть Италии, остготы начали повальную конфискацию имущества поддерживавших их до этого римлян. Описывая нормы Прагматической санкции Юстиниана Великого (554 г. ${ }^{49}$, возвращавшей конфискованные землевладения итальянским церковникам и аристократам, Зинаида Удальцова подчеркнула: «Захваты и конфискация не уничтожили тогда полностью крупное землевладение, но нанесли ему очень тяжелый удар, от которого оно так и не смогло полностью оправиться, несмотря на все предписания Прагматической санкции и других законодательных актов Юстиниана, целиком направленных на реставрацию этой формы земельной собственности» 50 .

В конце 542 г. Юстиниан назначил полководца Максимина одновременно префектом претория и главнокомандующим Италии. Это означало, что Константинополь принимает меры к распространению на Италию общеимперской формы административной власти. В некотором смысле, назначение Максимина было шагом к административной

47 Procop. BG, III.6.5; 13.1.

48 Greg. I. Dial., I.2. Факты притеснений и разорений ортодоксальной Церкви со стороны еретиков-ариан: Greg. I. Dial., II.14, 15, 51.

$49 \mathrm{O}$ «Прагматической санкции» 554 года см.: Курбатов Г. Л. Там же. С. 254.

50 Удальцова 3. В. Там же. - с. 347. 
вертикали, существовавшей при Теодорихе Великом (493-526), Аталарихе (526-534) и Амаласунте (534-535). Вся военная и гражданская власть теперь концентрировалась в руках одного человека, который всецело отвечал перед императором Юстинианом. Для подкрепления префекта Максимина Юстиниан также выслал в Италию небольшие, но боеспособные воинские подразделения армян, гуннов и фракийцев ${ }^{51}$. Вполне возможно, что среди гуннов и фракийцев присутствовало какое-то количество славян. В любом случае необходимо помнить о присутствии славянского элемента на протяжении всей византийско-остготской войны. Еще в 537 г. славянскоантское подкрепление присылалось Юстинианом на помощь Риму, осажденному остготским королем Витигисом ${ }^{52}$.

Впрочем, Максимин, хотя и сосредоточил в своих руках полноту власти, не смог правильно ею распорядиться53. Гораздо больше надежд византийские солдаты возлагали на соратника Велизария - полководца Димитрия. Крупное поражение Димитрия от арьергарда Тотилы под Неаполем (пребывавшем в остготской осаде) сломило боевой дух армии. После следующего поражения Димитрий был взят в плен и принужден с веревкой на шее стоять перед воротами Неаполя и просить жителей города капитулировать перед войсками «великого Тотилы»54. Остготский король лично обещал Неаполю мир, в случае добровольной сдачи. Он заявил жителям Неаполя, что считает себя истинным королем готов и италийцев, и отдаст приказ щадить последних в этой войне. Византийскому гарнизону остготы гарантировали сохранение имущества и жизни. Прокопий сообщает, что жители Неаполя поддались обещаниям Тотилы и тот их полностью сдержал. Весной 543 г. город перешел под контроль остготов, а весь восточноримский гарнизон Тотила отправил в Рим, предварительно снабдив византийцев продовольствием. Это стало наверное самой крупной политической рекламой для короля, сослужившей ему прекрасную службу на протяжении дальнейших восьми лет. Впрочем, Тотила, помня об ошибках Витигиса (536-540) в первую итальянскую кампанию, на этот раз предпринимал все шаги для «обесточивания» военной энергии

51 Procop. BG, III.6.9-10.

52 Считаем верным предположение о славянском характере «гуннов», упомянутых в трактатах Прокопия. Сами гунны были уничтожены германцами и славянами еще в 450-х гг. Их название, как и этнонимы «скифы» / «сарматы», автоматически закрепилось за оставшимся населением Восточной Европы. Среди этого населения преобладали германцы и славяне.

53 Procop. BG, III.6.12-13; 7.1-3.

54 Procop. BG, III.7.8-9. 
византийцев. В частности, при захвате итальянских городов Тотила занимался уничтожением укреплений, чтобы избежать возможного возврата городов под византийский контроль и дальнейшей осадной войны. Вся его тактика базировалась на сражениях в открытом поле, где остготы могли продемонстрировать напор и бесстрашие. Остготы намного хуже воевали в осадных и оборонных условиях.

В 543-544 гг. Тотила укреплял власть на южных территориях. Центральная Италия практически полностью покорилась. Вокруг Вечного города сжималось новое кольцо. Разгром византийского флота под Неполем позволил Тотиле приступить к созданию остготского флота. Основой военно-морских сил были захваченные неапольском бою корабли. При этом, флотские и сухопутные соединения остготов пополнялись огромным количеством рабов и зависимых крестьян, рекрутацию которых Тотила поощрял на землях Центральной Италии.

Весной 544 г. остготами была захвачена Калабрия. Под контролем византийцев оставался только важнейший порт Гидрунт (теперь Отранто)55. Прокопий пишет, что к началу 544 г. «византийские начальники в укреплениях пировали вместе со своими возлюбленными, а солдаты, проявляя крайнее неповиновение начальникам, предавались всяким безобразиям»56. Моральное разложение многих восточноримских соединений было выгодно для Тотилы, демонстрируя контраст между его собственными «гуманностью и дружелюбием» и византийской «алчностью и беспечностью».

Тотила показательно наводил порядок в войсках, предавая смертной казни всех дизертиров и мародеров. Уловив момент, Тотила начал притеснять земельных аристократов, получая взамен поддержку широких слоев зависимого и полузависимого крестьянства. Здесь он и черпал силы для пополнения собственной армии. Римские землевладельцы очень сильно просчитались, поставив на Тотилу. Он воспользовался их неудовольствием оплаты больших налогов и начал, в итоге, собственную социальную политику. Аристократы попали в немилость как византийцев, так и остготов. Чем больше территорий переходило под контроль Тотилы, тем меньше он сдерживал собственных солдат в их желании мстить сенаторам бывшим хозяевам. В итоге, аристократические землевладения грабили намного чаще и жестче, нежели взятые штурмом города. Комит Марцеллин, например, сообщает, что в крепостях Фирм и Аскул остготы

\footnotetext{
55 Procop. BG, III.9.4.

56 Procop. BG, III.9.1.
} 
пощадили всех византийских солдат, сохранив им имущество, свободу и военную амуницию, но перебили почти всех местных жителей ${ }^{57}$.

В конце 545 г. Тотила приступил к осаде Рима.

Уже длительное время кольцо вокруг Вечного города сжималось и теперь, полностью завоевав Центральную Италию, Тотила мог себе позволить совершить важный символический шаг. Известно, что Тотила писал письма для римского сената, обещая полное прощение византийских симпатий в том случае, если сенаторы осознают единство и неразрывную связь политических интересов германцев и римлян на территории Италии.

В первом послании к сенаторам Тотила объявил о сплошной неблагодарности римских аристократов, которые получили от Теодориха и Амаласунты все, что только могли. Несмотря на «черную неблагодарность» сенаторов Тотила считал свою армию истинной защитницей римлян от «посягательств» Византии. Он даже назвал остготов «мстителями» византийцам за финансовые и хозяйственные притеснения. Тотила считал, что настоящий мир невозможен без союза сенаторов и остготов. Для этого Вечному городу нужно было немедленно сдаться королю58.

Письмо Тотилы приехало в Рим вместе с очередной группой отпущенных на свободу пленных византийцев. Прокопий сообщает, что сенаторы не изъявили желания идти на мирное соглашение с королем, что, очевидно, объясняется ужесточением остготской политики в аграрной сфере (в то время начались серьезные нападения на большие землевладения аристократов, поголовное переманивание сенаторских рабов в остготскую армию). Однако, Прокопий также отдельно ссылается на решение командира римского гарнизона Иоанна, запретившего сенаторам отвечать на любые обращения короля ${ }^{59}$. Как отмечает 3. В. Удальцова, «примирению Тотилы с римским сенатом в первую очередь, конечно, мешало то, что остготское правительство не могло отказаться от тех социально-экономических мероприятий, которые задевали интересы сенаторов, но в то же время обеспечивали Тотиле его успехи. Поэтому все попытки этого остготского короля сблизиться с сенаторами были обречены на провал, даже в тех случаях, когда сенаторы и не боялись мести императора за переход на сторону Тотилы»60.

После неудачной попытки перемирия с сенаторами, Тотила

\footnotetext{
57 Marc. Chron., a. 545.

58 Procop. BG, III.9.7-18.

${ }^{59}$ Procop. BG, III.9.20.

60 Удальцова 3. В. Там же. - с. 358.
} 
повернул пропаганду в обычное демагогическое русло. По ночам во многих местах Рима развешивались политические прокламации, которые призывали римлян к восстанию и к переходу на сторону «правителя Италии» Тотильб1. Прокопий сообщает, что распространением прокламаций, вероятно, занимались арианские священники 62 , которые, как это ни странно, оставались на подконтрольных византийцам территориях нетронутыми. Необходимо отметить: прокламации Тотилы, как и массовое участие италийских зависимых крестьян $b$ остготской армии, рождали новую политическую идентичность на Апеннинском полуострове. Сегодня эта идентичность известна как итальянская. Конечно же, формирование современного итальянского этнического организма находилось на зародышевом этапе. Итальянцев ещзе не было. Но ощущение возможности политического самоопределения появлялось. Оно было неотделимо от "римской идеи», но впервые показывало, что идея эта может быть понята иначе, чем элиниистическое «вселенское единство» (Ойкумена).

Позитивное восприятие прокламаций Тотилы итальянским населением очень показательно. Всего за два года власти византийцы сумели настроить итальянские массы против себя. Конечно же, остготы являлись государственными преступниками, борющимися против законной императорской власти. Конфликт не переставал быть гражданской войной. Но социально-экономическая обстановка внутри Италии способствовала предательской линии крупных землевладельцев. Персидские дела (намного более опасные, нежели бунт короля Тотилы) и продолжительная болезнь не позволяли императору приступить к организации мирного жизнеустройства в Италии. Тотила сумел воспользоваться этим уникальным историческим шансом и затянул разрушительную гражданскую войну еще на десять лет.

Падение Неаполя в начале 543 г. стало для Юстиниана неожиданностью. Ведь император лично распорядился организовать запасы продовольствия в этом важном портовом городе и отправил для обороны мощные восточноримские отряды. Неаполь считался ключом к Южной Италии и «междуостровного» Средиземноморья (морское пространство между Сицилией, Италией, Сардинией и Корсикой). Интересно, что именно Неаполь был избран остготами в качестве символической столицы. Тотила оттуда обращался к сенаторам и жителям Рима, призывая итальянских граждан поднять «антиэллинское» восстание.

Так или иначе, «всеобщее восстание» в значительной степени не

\footnotetext{
61 Procop. BG, III.9.20-21.

62 Procop. BG, III.9.21.
} 
началось из-за позиции римских патрициев, которые после длительных дискуссий в сенате, предпочли «римскую идею» (ортодоксальнохристианскую) идее «остготской Италии» (арианской). Весомые аргументы для римлян составила также нерушимая позиция полководца Иоанна и новость о прибытии Велизария.

Как мы помним, Велизарий, после майской победы 540 года, был отправлен на восточный фронт. Занимаясь организацией боевых действий против персов, Велизарий попал в опалу. По всей видимости, здесь играли роль не только внутренние интриги константинопольского двора, но и старое предложение Витигиса о провозглашении Велизария западным императором (540 г.). Комит Марцеллин писал: «Велизарий, отозванный с Востока для отражения врага, сам попал в опасное положение, впав в немилость, и был затем отослан обратно в Италию»63. Прокопий, $b$ свою очередь, сообщает, что Юстиниан и Феодора подозревали Велизария в присвоении больиих сумм из сокровищнии, королей Гелимера и Витигиса. Именно поэтому Юстиниан вызвал Велизария к себе и предложил ему возврат полководческих полномочий только в случае, если Велизарий за свой счет соберет и экипирует экспедиционный корпус ${ }^{64}$. Велизарию пришлось согласиться. Летом 544 г. он организовал 4-тысячный фракийскоиллирийский отряд и, совершив переход через Далмацию, в декабре 544 г. вошел в Равенну.

Впрочем, прибытие Велизария добавило осажденным римлянам только моральные силы. Материальной мощи не прибавилось. Византийская армия продолжала терпеть тяжелые поражения. Остатки византийских войск на севере и юге сдавались Тотиле. Известен случай полного перехода сполетского гарнизона на сторону остготов. Возглавлявший этот гарнизон Иродион вступил в личный конфликт с Велизарием, предал противнику город, свое войско и перешел на службу к Тотиле. Это предательство Иродиона сильно ударило по военной кампании, вынуждая Велизария перейти к оборонительным действиям в Равеннском регионе. На севере Италии произошел также мятеж иллирийских солдат Велизария.

Весь 545 г. византийцы сдавали позиции в разных частях Италии. Комит Марцеллин писал, что в 545 г. «Тотила, опустошив Пицен, сражаясь, одержал победу при Ауксиме, а оттуда двинувшись через Тусцию разрушил Сполеций, захватил города Асизий и Клузий и осадил

\footnotetext{
63 Marc. Chron., a. 545.

64 Procop. BG, III.10.1.
} 
Перузию»65. Таким образом, предполагаемые наступательные действия прославленного полководца Велизария захлебнулись в самом начале.

Военная осада Рима остготами началась в декабре 545 г.66. Полтора года продолжались упорные бои вокруг «вечного города», стоившие мировой культуре множества памятников древнеримского зодчества и искусства. Второй раз за десять лет все пригороды Рима были сожжены, а население уничтожено. Положение осажденных оставалось очень плохим на протяжении всего времени сражения.

В первую очередь, Тотила, захватив Неаполь, Кум, Тибур, Лаций, Кампанию и Самний, лишил римлян возможности получать продовольствие сухопутным путем. Созданный остготами флот базировался теперь в Неаполе и на Эоловых островах, откуда совершал вылазки против византийцев. Папа Римский Вигилий успел перебраться на Сицилию, оставив во главе Рима диакона Пелагия 67 . Вигилий оставался верным императору и предпринимал всевозможные усилия для организации отпора остготам. Папа Римский лично оплатил и собрал группу кораблей с продовольствием, которые должны были тайно доставить еду по Тибру в Рим. Но остготский флот уничтожил эти корабли, а большая делегация папской свиты попала в плен. После допроса папские легаты были изрублены мечами. Тотила лично приказал отрубить обе руки приближенному к Вигилию епископу Валентину.

Когда последняя возможность получить продовольствие была утрачена, в Риме начались волнения. Жители города требовали сдачи города остготам, если в самое ближайшее время не подойдут византийские подкрепления 68 . Командир гарнизона Бесса фактически самоустранился от ведения дел и передал все полномочия Пелагию. Диакон начал переговоры с Тотилой, но остготский король отверг все предложения Пелагия. Для остготов больше не могло быть никаких условий со стороны римлян. Тотила считал, что теперь он могуществен как никогда и слушать римских аристократов больше не хотел. Тотила даже отказался обсуждать возможность возврата беглых рабов их старым владельцам ${ }^{69}$. Остготский король отослал посольство Пелагия назад в Рим, а сами остготы продолжили ожидание под стенами Рима, в котором осенью 546 г.

\footnotetext{
65 Marc. Chron., a. 545.

66 Procop. BG, III.13.1. Комит Марцеллин считает, что остготы приступили к штурму Рима в начале 546 г. - Marc. Chron., а. 546.

${ }^{67}$ Lib. Pont. V. Vigil., 8.

68 Procop. BG, III.16.7.

69 Procop. BG, III.16.8-32.
} 
разразился страшный голод. Он и решил судьбу города... Как оказалось, полководцы Бесса и Конон спрятали часть продовольствия на личных складах и занимались спекуляцией, продавая вдесятеро дороже продукты питания знатным римлянам. И это тогда, когда «вся масса народа питалась преимущественно крапивой, которой много росло всюду вокруг укреплений, в развалинах на пустырях города; многие под давлением голода сами на себя накладывали руки, так как не моли уже найти ни собак, ни мышей, ни трупа другого какого-либо животного, которым бы они могли питаться» 70 .

Настоящая катастрофа произошла в ночь на 17 декабря 546 г., когда отряд голодающих исаврийцев открыл Азинариевы ворота остготам ${ }^{71}$.

Прокопий отмечал, что после устроенной германцами резни, в Риме осталось лишь 500 жителей «из простого народа»72. Огромное количество римлян убили, но еще больше граждан города вынуждены были покинуть его. Комит Марцеллин подчеркивает: «Тотила, благодаря измене исавров, вступил в Рим на 16-й день январских календ, стены его разрушил, дома сжег и имущество всех римлян захватил в качестве добычи; а самих же римлян, взятых в плен, отвел в Кампанию; после этого разграбления в течение 40 или более дней Рим был совершенно безлюден, и не оставалось там ни человека, ни какого-либо животного»73.

Тотила отдал город на полное разграбление своим войскам ${ }^{74}$. Убийства жителей города продолжались всю ночь с 16 на 17 декабря, о чем сообщает Прокопий. Он подчеркивает, однако, что остготы прекратили массовые убийства на следующий день, убивая только тех, кто попадался им навстречу. В целом, интересно, что Прокопий положительно относится к Тотиле, который, по его мнению, отдал приказ «остановить бойню»75. Он «запретил в дальнейшем готам убивать кого бы то ни было из римлян»76. Прокопий также пишет: «Из ценностей Тотила велел самое дорогое отобрать для себя, все же остальное позволил военным грабить, как они хотят. Много богатства нашел он в домах патрициев, но особенно много в логове Бессы; этот проклятый негодяй бессовестно собрал для Тотилы

\footnotetext{
70 Procop. BG, III.19.

71 Procop. BG, III.20.15-17.

72 Procop. BG, III.20.19-20.

73 Marc. Chron., a. 547.

${ }^{74}$ Iord. Rom., 380.

75 Procop. BG, III.20.25.

76 Procop. BG, III.20.25.
} 
груды золота, вырученного за продажу хлеба»77. Тотила собрал вокруг себя многих знатных римских пленников и, говоря им о византийцах, перешедших на сторону остготов, заявил: «Вы теперь будете на положении рабов, эти же, будучи друзьями готов, естественно, став им близкими, будут в дальнейшем нести те должности, которые вы несли прежде»78. С декабря 546 г. Тотила приступил к политике «решительного устрашения римской аристократии» ${ }^{79}$.

Как пишет Иордан, в 546 г. Тотила «опустошил всю Италию и занял Рим, разрушил укрепления всех городов, а всех сенаторов, ограбив, после того как был разрушен Рим, переселил в Кампанию»80. Остатки населения Рима были в полном составе переселены в Кампанию, а сенаторы попали $b$ плен к Тотиле. Значительные успехи короля Тотилы сопутствовали реорганизации политической программы остготов.

Уже в 547 г. король отправил посольство к Юстиниану, которое возглавили диакон Пелагий и ритор Феодор. Это посольство предложило Юстиниану те же самые условия мира, на которых Италией правили Теодорих Великий и Амаласунтав․ Тотила говорил о том, что согласен признать верховную власть императора точно так же, как её признавали Теодорих и Амаласунта. В территориальном отношении Византия должна была уступить остготам всю Италию, Далмацию и Сиицлию, а остготы взамен вновь считались бы де-юре частью Восточной Римской империи. Таким образом, речь шла о восстановлении права foedus ${ }^{82}$. В случае несогласия императора с его условиями, Тотила рискнул угрожать Империи убийством всех пленных римских сенаторов и началом военных действий в провинции Иллирик. Несмотря на эти угрозы, Юстиниан, помня о предательском отношении многих аристократов к Империи, ответил Пелагию отказом и выдвинул единственное условие мира - капитуляцию остготской армии. Как резюмирует Джон Джулиус Норвич, - «хотя падение Рима и не являлось серьезным поражением в стратегическом смысле, как символическое событие оно имело исключительное значение, и Тотила сразу же предложил византийцам мир. Но условия договора, предложенного готами,

\footnotetext{
77 Procop. BG, III.20.25-26.

78 Procop. BG, III.21.12-16.

79 Удальцова З. В. Там же. - с. 379.

80 Iord. Rom., 379-380.

81 Procop. BG, III.21.18-25.

82 Procop. BG, III.21.18-25.
} 
были отвергнуты императором, и бои возобновились»83.

Противостояние с остготами в 546 г. развивалось очень плохо для восточных римлян, даже в сравнении с 542-543 гг. Византийцы потеряли большую часть Апеннинского полуострова. Остготы полностью переключили свое внимание на Калабрию и приморские части Южной Италии. Здесь собрались силы последних итальянских аристократов и сенаторов, осознавших губительные последствия сотрудничества с остготами. Борьба развивалась вокруг нескольких важнейших портовых центров - Гидрунта (Отранто) в Калабрии и Росцианы в Бруттии ${ }^{84}$. Исследования Э. Штейна доказывают, что сопротивление остготам на Юге Италии постепенно превратилось в общенародное движение ${ }^{85}$.

Еще в 543 г. во главе апулийских аристократов встал крупный землевладелец Туллиан. Он прямо обратился к византийскому полководцу Иоанну (закрывшемуся с гарнизоном в Гидрунте) с заверением в верности южноитальянских аристократов императору, но также и с требованием прекратить налоговые притеснения после победы над остготами ${ }^{86}$. Туллиан сумел объединить разношерстные социальные силы (землевладельцев, аристократов, свободных и полузависимых крестьян) в противостоянии остготам. В дальнейшем развитию провизантийского движения Туллиана способствовала политика, проводимая Тотилой в Риме и прочих регионах, которая была направлена на подавление ортодоксальной Церкви и уничтожение знати. Для организации подрывной работы в Калабрии и Бруттии Тотила присылал туда «многочисленные банды крестьян под командованием готских офицеров» ${ }^{87}$. Боевые действия перенеслись на самый юг Апеннин. Именно поэтому рывок Велизария к Риму был воспринят византийцами как большая победа. Сначала греческий отряд Мартиниана сумел захватить Сполето, а в апреле 547 г. византийский корпус Велизария смог ворваться в Рим и быстро овладеть городом.

Все авторы того времен подчеркнули огромное политическое значение захвата Рима 8 . Прокопий назвал действия Велизария «актом государственной мудрости», поскольку контроль над Римом позволял

83 Норвич Д. История Византии. История Венецианской республики. / Джон Норвич. - М.: АСТ: Астрель, 2011. - с. 88.

84 Procop. BG, III.22.22.

85 Stein E. Histoire du Bas-Empire. - t. II. - p. 579-582.

86 Procop. BG, III.18.20-23.

87 Stein E. Histoire du Bas-Empire. - t. II. - p. 584.

88 Procop. BG, III.24.1; Marc. Chron., a. 547; Mar. Avent., a. 547; Iord. Rom., 380. 
говорить о возврате инициативы в руки византийцев ${ }^{89}$. Комит Марцеллин, вторя Прокопию, подтверждает широкий размах инженерных работ, предпринятых Велизарием во вновь обретенном Риме 90 . Полководцу понадобилось 25 дней усиленной работы для восстановления городской стены и организации крупного склада продовольствия91. Велизарий публично объявил населению Рима, что он пришел назад для восстановления былого величия Вечного города.

Узнав о захвате Рима, Тотила бросился к Вечному городу и попытался немедленно его вернуть ${ }^{92}$. Сильное поражение, которое Тотила потерпел под стенами Рима, активизировало остготскую оппозицию93. Для подготовки к новым атакам восточных римлян Тотиле пришлось оставить попытки захватить Рим и закрепиться с основными силами в Тусции ${ }^{94}$ В свою очередь Иоанн, совершил «дерзкую» вылазку из Южной Италии в Кампанию, где сумел спасти из остготского плена многих римских сенаторов и их семьи ${ }^{95}$. Это стоило Иоанну потери большей части Южной Италии. Армия Тотилы совершила масштабное вторжение на подконтрольные византийцам районы Лукании. Велизарию пришлось двинуться на помощь южанам, оставив в Вечном городе внушительный гарнизон $^{96}$. В итоге, вылазка Велизария потерпела неудачу из-за внутренних противоречий в армии. Оставшийся в Риме гарнизон поднял мятеж и объявил о возможной сдаче Тотиле, если не будет выполнены требования по уплате задолженного жалования. Велизарию пришлось потратить много времени на решение этой проблемы, но ультиматум гарнизона, что очень интересно, был полностью принят, а сами мятежники амнистированы ${ }^{97}$. Однако, потеря византийцами Росцианы на юге, вновь позволила остготам взять инициативу в свои руки. Теперь они угрожали даже Сицилии. Вот почему Велизарий, потерявший благодаря этим поражениям политический авторитет, подал прошение об отставке (конец 548 г.). В ответ Юстиниан отозвал Велизария в Константинополь 98 . Джон

\footnotetext{
89 Procop. BG, III.24.1.

90 Marc. Chron., a. 547.

91 Procop. BG, III.24.7.

92 Mar. Avent., a. 547.

93 Procop. BG, III.24.29.

94 Procop. BG, III.24.31.

95 Procop. BG, III.26.12.

96 Procop. BG, III.27.4-17.

97 Procop. BG, III.30.7-8.

98 Procop. BG, III.30.3.
} 
Норвич, основываясь на «Тайной истории» Прокопия, считает, что это случилось вследствие нежелания Велизария нести ответственность за предрешенную капитуляцию остатков армии. Это безусловно играло определенную роль, но все же удовлетворение Юстинианом прошения полководца в большей мере объяснялось опасениями перед крупномасштабным персидским вторжением на восточных границах. Иордан также подчеркивает, что причиной отставки Велизария послужила смерть жены Юстиниана Феодоры (28 июня 548 г.), составлявшей протекцию для Антонины - жены Велизария99.

Пока Юстиниан обращал свои взоры к тлеющему персидскому конфликту, а византийские войска Италии находились в замешательстве, Тотила совершил разрушительные пиратские набеги на далматинское побережье Восточной Римской империи (весной 549 г.). Папа Вигилий постоянно обращался к Юстиниану с просьбами о помощи, но Юстиниан, узнав о новых заговорах и интригах, расцветавших в Константинополе, откладывал личное вмешательство ${ }^{100}$.

Итальянская кампания вступила в самую жаркую для Константинополя фазу. Остготам удалось договориться с некоторыми другими германскими племенами, контролировавшими паннонскую низменность. Варвары начали организованные нападения по всей линии соприкосновения с Восточной Римской империей. Франки полностью оккупировали Венетию, гепиды вторглись в Дакию, славяне во Фракию, лангобарды осуществляли масштабные грабительские атаки по всей территории Далмации, а герулы разбили лагерь под Сингидуном (современный сербский Белград) ${ }^{101}$. Прокопий сообщал даже, что лангобардский король Ильдигис, объединив шесть тысяч гепидов и славян, объявил о своем подчинении Тотиле ${ }^{102}$. Говоря об остготском наступлении в Италии, набегах на Далмацию и Иллирик, персидской войне в Месопотамии, Прокопий написал горькие слова: «Так поделили между собой варвары Римскую империю»103.

Уже 16 января 550 г. остготы, пользуясь очередным предательством исавров, вновь захватили Рим ${ }^{104}$. Взяв под контроль Вечный город, король Тотила объявил о «возрождении» Рима. Теперь город вновь должен был

\footnotetext{
${ }^{99}$ Iord. Rom., 381-382.

100 Procop. BG, III.31-32.

101 Удальцова 3. В. Там же. - с. 394.

102 Procop. BG, III.35.20-22.

103 Procop. BG, III.34.1.

104 Malal., p. 483.
} 
стать столицей. Тотила применял силу для заселения Рима, вселяя в заброшенные дома жителей окрестных провинций. В честь «восстановления остготской столицы» король провел большие игры. Это должно было не только придать авторитет королю или склонить итальянское население на сторону остготов, но и продемонстрировать, что теперь Тотила останется в Риме надолго. В связи с этим, Тотила несколько раз (в 550 г.) обращался к Юстиниану Великому с просьбой об установлении мира на условиях сохранения договоренностей Теодориха Великого (493-526) и Зенона (476-491), достигнутых в 488 году105.

Юстиниан не просто отказался от мирных предложений Тотилы, но и назначил нового итальянского главнокомандующего - Германа ${ }^{106}$. В ответ остготы совершили разрушительный набег на Сицилию. Но, как подчеркивает 3. В. Удальцова, сицилийский поход остготов выглядит весьма странным, поскольку располагая преобладающими силами и вполне использовав эффект неожиданности, остготы все же оставили остров и вернулись в Италию (с четырьмя сотнями военных кораблей, доверху нагруженными награбленным имуществом) ${ }^{107}$. Это можно объяснить только двумя причинами. Во-первых, армия Тотилы выдохлась за девять лет беспрерывной войны. Во-вторых, в отношении политики Тотилы была выстроена достаточно серьезная линия оппозиции. Теперь Тотиле приходилось считаться с серьезными противоречиями внутри остготской знати. Возможно, что именно поэтому Тотила чаще обращался к Юстиниану с безответными просьбами о заключении мира.

Осенью 550 г. двоюродный брат императора и итальянский главнокомандующий Герман умер. На эту должность был назначен его зять Иоанн $^{108}$. В боевых действиях наблюдалось некоторое затишье, которое можно объяснить подготовкой обеих сторон к решающему сражению. В начале 551 г. 300 военных кораблей остготов напали на берег Эпира и разграбили остров Корфу. В ответ, византийцы нанесли сокрушительное поражение остготскому флоту возле Сенигаллии (Сены Галльской)109. Остготы предприняли высадку на византийских островах Сардиния и

105 Procop. BG, III.37.6-7; IV.24.4-5.

106 Герман, двоюродный брат Юстиниана Великого, женился вторым браком на Матасунте, дочери Евтариха и королевы Амаласунты, сестре короля Аталариха. Таким образом, род императора Юстиниана вступил в непосредственное родство с династией остготских королей Амалов.

107 Procop. BG, III.37.5.

108 Procop. BG, III.40.10.

109 Procop. BG, IV.23.41. 
Корсика. Для изгнания остготов Юстиниан направил ливийского наместника Иоанна Троглиту, который потерпел поражение на острове Сардиния (возле стен Кальяри) ${ }^{110}$.

Разгромив оплаченные Тотилой славянские отряды на Балканах ${ }^{111}$, Юстиниан Великий назначил новым главнокомандующим евнуха Нарсеса (весной 551 г.).

Благодаря хроникам Прокопия Кесарийского, Мария Аваншского, Агафия Миринейского, Иордана Готского биография Нарсеса хорошо изучена. Известно, что Нарсес родился около 478 г. на территории персидской Армении. В дальнейшем он попал в византийское рабство и был превращен в придворного евнуха. Постепенно Нарсес занял должность офицера и командира отряда императорских евнухов-телохранителей. В 531 г. он был послан Юстинианом на тайные переговоры с армянскими генералами, находившимися на персидской службе. В итоге армянская знать перешла на византийскую службу, а Нарсес получил должность главного казначея Восточной Римской империи. В 532 г., во время восстания в Константинополе против Юстиниана, главный казначей не только поддержал законного императора, но и рискуя жизнью переманил на его сторону городскую знать. Кроме того, Нарсес возглавлял отряд по уничтожению бунтовщиков. Юстиниан не забыл об этом и назначил Нарсеса в 538 г. на должность первого советника императора, сохранив за ним также титул главного казначея. Итальянское войско Нарсес возглавил в возрасте 74-х лет.

Нарсес почти на год задержался во Фракии, где командовал армией противостоящей славянскому вторжению ${ }^{112}$. Осенью 551 г. Нарсес был уже в Салоне (современном хорватском Сплите), занимаясь организацией и экипировкой итальянской экспедиционной армии. Юстиниан Великий официально объявил Нарсеса правителем и диктатором Италии на время военных действиї113.

Становится очевидным, что в 552 г. Юстиниан обладал уже достаточной твердостью власти для того, чтобы вернуться к решению итальянских проблем. Под руководством полководца Нарсеса 35 тыс. византийцев совершили поход в Италию по суше, проходя территории современных Хорватии и Словении. Начался далматинский поход Нарсеса 552

\footnotetext{
110 Procop. BG, IV.24.31-39.

111 Procop. BG, III.40.32.

112 Malal., p. 480.

113 Procop. BG, IV.21.5-6.
} 
года, итоги которого сыграли главную роль для дальнейшего поражения остготов. К этому моменту противоборствующие стороны прекрасно понимали, что новый виток боевых действий станет решающей битвой. Эту решающую кампанию в Италии подготовили разгром славян во Фракии и германских племен на Балканах в 551 г.

Для того, чтобы избежать возможного столкновения с франками и отрядами военачальника Тейи, Нарсес двинулся прямо вдоль Адриатического побережья (Истрия), где ему помогали соединения из равеннского гарнизона. Таким образом, прямо вдоль Адриатики двигалось огромное войско, которое численно уничтожило бы любую нападавшую силу. Это обезопасило Нарсеса от горных истрийских засад и позволило триумфально войти в Равенну ${ }^{114}$.

Прокопий сообщает о том, что в начале лета 552 г. «уныние духа и ума» охватило готов ${ }^{115}$. Внутриполитические конфликты привели к тайным переговорам между противниками Тотилы и командующим Гидрунтского гарнизона Пакурием. Понимая, что нарастание оппозиции зависит от передвижений Нарсеса, Тотила начал искать возможность сразиться с византийцами в открытом поле. «Момент истины» многолетнего конфликта настал в конце июня 552 г. Обе армии встретились на севере Центральной Италии, возле современного Гвальдо Тадино (тогда Тагина). Армии расположились друг против друга на землях долины Busta Gallorum, что означает «долина Галльских погребальных костров». Место для сражения было избрано очень символическое. Его название осталось со времен величайшего сражения римлян и кельтов (галлов), в результате которого кельтской (галльской) армии был нанесен непоправимый ущерб, а римляне подтвердили политический имидж правителей Европы ${ }^{116}$.

Новая битва на «Галльских погребальных кострах» начиналась очень долго. Несколько дней Тотила и Нарсес подогревали боевой дух своих воинов. Тотила всячески пытался оттянуть начало генерального сражения, так как ожидал прибытия двух тысяч конников. Король даже упражнялся перед строем остготской армии в искусстве верховой езды, параллельно отсылая посольства в обоз Нарсеса. Тотила дождался большого подкрепления и первый начал битву. Вся остготская конница ринулась в

114 Procop. BG, IV.26.24.

115 Procop. BG, IV.26.4.

$116 \mathrm{O}$ «Галльских погребальных кострах»: Hartmann L. M. Geschichte Italiens. / L. M. Hartmann. - Bd. I. - Gotha, 1897. - s. 321. Особенно обратите внимание на военное описание: Delbruck H. Geschichte der Kriegkunst. / H. Delbruck. - Bd. II. - Berlin, 1921. - s. 374-386. 
ряды византийцев, но была остановлена градом стрел. Искусство византийских лучников заставило остготов обратиться в бегство, которое по инерции увлекло за собой готовых атаковать пехотинцев. Весь день Тотила и Тейя провели в попытках восстановить ряды остготской армии, спасая остатки кавалерии. Вечером византийская армия, при деятельном участии лангобардских, герульских и славянских подразделений, нанесла непоправимый ущерб остготам. Нещадно уничтожались отряды византийцев-дезертиров, служившие Тотиле. Сам Тотила был ранен и перенесен верными остготами в городок Капрару. Здесь он и умер. Шеститысячный отборный корпус остготов сдался Нарсесу. Летописец Ландольф так описал исход сражения: «Когда готы почти все были перебиты, Нарсес убил короля Тотилу, который царствовал уже свыше десяти лет; окровавленные же его одежды и корона, украшенная драгоценными камнями, были отосланы $b$ изарственный град Константинополь и брошены к ногам императора $b$ присутствии сената» 117.

Интересно, что византийцы решили удостовериться в смерти Тотилы. Специальный отряд занял Капрару, где труп Тотилы откопали, опознали и вновь похоронили. В это же время, остготская военная знать, выжившая на «Галльских погребальных кострах», отступила на север от реки По, где был созван новый военный совет. В большой спешке остготы избрали новым королем молодого военачальника Тейю118. Остатки военной казны Тотилы, Тейя решил использовать для покупки франкского участия в противостоянии. Иного выхода остготы уже не видели. Понимая, что генеральная победа Нарсеса принесет Византии долгожданный контроль над Центральной Италией, а гидрунтский гарнизон вот-вот очистит юг Апеннин, остготы обратились к франкским королям-Меровингам ${ }^{119}$.

Франки действительно выступили к Вероне, благодаря чему город остался под контролем остготов. Нарсес, не желая воевать в данный момент с франками, совершил переход к Риму, подчиняя своей власти все окрестные территории. Корпус Дагисфея вошел в Вечный город первым. Остатки остготского гарнизона закрылись в мавзолее Адриана, где остготам оказывали ожесточенное сопротивление сами византийцы еще в 546 г.

После кратковременного противостояния, в июле 552 г. Рим вновь оказался под контролем армии Восточной Римской империи. Нарсес совершил обряд триумфального вступления в город и выслал Юстиниану

\footnotetext{
117 Landolf., XVIII.19.

118 Mar. Avent., a. 553; Agn., 62.

119 Procop. BG, IV.33.7.
} 
символические ключи от римских ворот ${ }^{120}$. Потеря Рима озлобила окружение Тейи. Политическая коммуникация между остготским севером и югом была вновь прервана, только теперь остготы уже не имели достаточно воинов для быстрой мобилизации. В результате, остготы казнили триста сенаторских детей, взятых ранее Тотилой в заложники. Также остготы осуществили массовые убийства сенаторов и римских аристократов, земледельцев Кампании. Подразделения остготов-южан занимались физической ликвидацией всех, кто пытался вернуться в Рим или перейти на территории, подконтрольные Нарсесу ${ }^{121}$.

Король Тейя послал новых переговорщиков к Меровингу Теодебальду, который отказал ему в просьбе помочь вторжением. Для того, чтобы спасти родного брата, командовавшего осажденным в Кумах гарнизоном, Тейя с верными силами прорвался на юг. Остготский флот, тем временем, сдался византийцам. Благодаря этому Тейя перестал получать продовольствие морем, в остатках армии царили голод, паника и неразбериха. Остготские гарнизоны по всей Италии массово переходили на сторону Византии. Голодная «гвардия» Тейи заняла современный Монте Латтаро - «Молочную гору». В момент, когда большая часть остготских владений вновь была подчинена византийцами, флот полностью капитулировал, из Балкан и Сицилии прибывали все новые подкрепления императорских солдат, а голод истощал верных остготов, Тейя принял решение атаковать Нарсеса.

Нельзя не согласиться с утверждением 3. В. Удальцовой о том, что битва на Молочной горе в октябре 552 г., «принадлежит к наиболее героическим страницам истории войны в Италии»122. Вероятно, что это сражение должно войти в анналы мировой истории как отчаянная битва за доблестную и не голодную смерть. Прокопий написал: «Готов воодушевляло отчаяние, римляне же стыдились уступить более малочисленным противникам и выдерживали их натиск. Те и другие с яростью устремлялись друг на друга; одни искали смерти, другие славы»123. Октябрьская битва на Молочной горе решила не только судьбу преемника Тотилы короля Тейи, но и судьбу германского политического владычества в Италии. Вместе с Тейей погибли все остатки готской армии. Сам король беспрестанно находился в самой гуще сражения, на переднем

\footnotetext{
120 Procop. BG, IV.33.13-27.

121 Procop. BG, IV.34.2-6.

122 Удальиова 3. В. Там же. - с. 419.

123 Procop. BG, IV.35.21.
} 
краю нападающих. Он погиб от византийского дротика, после чего восточные римляне отрубили королю голову ${ }^{124}$. Несмотря на утрату вождя, остготы сражались до поздней ночи следующего дня.

Дополнительные сутки битвы значительно ослабили силы Нарсеса и он был вынужден согласиться на переговоры с остатками остготских войск. Между Нарсесом и делегацией остготов было заключено октябрьское соглашение 552 г., согласно которому Нарсес позволял остаткам остготской армии сохранить собственное имущество и оружие и навсегда удалиться на север от реки По. Кроме того, если проигравшие отказывались удаляться из Италии, они обязаны были признать себя подданными византийского императора и торжественно клялись никогда больше не вступать в военное противостояние с Империей. Этим соглашением с византийским военачальником, остготы официально признали себя мятежниками, восставшими против законной власти Юстиниана. В награду за свою исключительную храбрость на Молочной горе, они получали амнистию и прощение. Эти условия касались одной тысячи остготов, выживших во время битвы ${ }^{125}$. Летописец Агафий подчеркивает: «И одни из них, жившие раньше южнее реки По, отправились в Тусцию и Лигурию и куда кто захотел, другие же, переправившись на ту сторону, расселились как и раньше, по Венетии около тамошних укреплений и городов» ${ }^{126}$. Но, хотя «всем казалось, что все войны в Италии кончились»127, вскоре начался новый виток боевых действий - вторжение франков (552-555 гг.)...

Впрочем, дальнейшая история сопротивления ряда остготских отрядов на Севере Италии, подкрепленная масштабной интервенцией франков, алеманнов и бургундов, не позволяет говорить о возобновлении политических структур остготов. Их королество прекратило свое существование как де-юре, так и де-факто. Чисто юридически, Остготское королевство в Италии пало еще 30 апреля 535 г., когда король Теодат (534536) предательски убил королеву-наместницу Амаласунту (534-535). С этого момента правление остготов на землях провинции Италии, являлось незаконным. Оно нарушало нормы личного права императора. Остготы убили Амаласунту, а затем и других константинопольских чиновников (Фиделия, Репарата), за что должны были ответить по закону. Италия являлась частью Восточной Римской империи. Следовательно,

\footnotetext{
124 Procop. BG, IV.35.20-30.

125 Procop. BG, IV.35.37.

126 Agath., I.1.

127 Agath., I.1.
} 
неподчинение остготов византийским властям считалось преступлением. Для ликвидации вооруженного мятежа варваров-федератов, Византии понадобилось осуществить в Италии две изнурительные военные кампании, которые с юридической точки зрения обладали признаками внутренней войны. Первая фаза гражданского конфликта кончилась сдачей остготами Равенны в мае 540 г. Но развертывание остготских сил и дипломатическое лавирование Ильдибада (540-541) и Тотилы (541-552) обеспечили продолжение войны. Вторая фаза активизировалась в 542 г., когда остготы начали свое победное шествие. К 550 г. остготы восстановили контроль над основными территориями и только полная концентрация внимания императора на подавлении их мятежа позволила повернуть варварские полки вспять. Битва на «Молочной горе» в октябре 552 г., когда после гибели Тейи готская знать подписала с Нарсесом договор о завершении войны и признании власти Юстиниана, означала фактический конец Остготского королевства. Остготы отказывались от всей территории Италии, давали согласие на полное свое переселение в северные районы Апеннинского полуострова. Важным для нас фактом есть то, что остготы дали согласие на подчинение императору Восточной Римской империи. Несмотря на акценты о территориальном расселении готов, юридический смысл согласия состоял в признании остготов самих себя подчиненными Византии независимо от собственно территориальной локации ${ }^{128}$.

В рассматриваемом здесь контексте международно-правовой истории, представляют громадный интерес не только политические события и общий ход боевых действий, но и бытовое отношение итальянцев к византийской власти. Описывая общую канву событий, мы уже обращали внимание на интересную закономерность. Если во время первой итальянской кампании (536-540гг.) римляне и латиноязычное население Италии оказывали огромную поддержку Велизарию и всем византийским подразделениям, то вторая итальянская война (541-552 гг.) показала, что итальянцы разделились, оказавшись на «баррикадах» различных противоборствующих сторон.

Итальянцы часто меняли даже политическую идентичность. Многие итальянцы римского происхождения называли себя готами, тогда как итальянцы готского происхождения записывались в «римляне».

128 О соглашении также см.: Agn., 79; Mar. Avent., a. 552, а. 553. 
Обработанные источники обращают пристальное внимание на факты многочисленных переходов с одной стороны на другую и наоборот. Нередкими, в этот раз (541-552 гг.), были случаи двойных и тройных дезертирств, предательств. Даже кадровые византийские военные неоднократно переходили на сторону Тотилы. В свою очередь, многие остготские военные сдавались византийцам. Некоторые исследователи считают этот факт признаком роста межэтнической розни в итальянском обществе (в частности, начальным этапом этнокультурной дифрференциации римлян и греков). Из их работ следует, что бытовая ненависть латинян к грекам (единоверцам и сообщникам в деле строительства античной культуры) выступила катализатором зарождения итальянского этноса ${ }^{129}$. В связи с этим фактом, считаем нужным подчеркнуть: в процессе формирования той народности, которая сегодня населяет Апеннинский полуостров, в дальнейшем принимали активное участие не только италоримляне и оставшиеся на полуострове германцы, но и другие различные племена, в том числе лангобарды (особенно с 568-572 гг.)130, арабы ${ }^{131}$, нормандцы ${ }^{132}$, славяне (это касается в большей мере северного региона -

129 Hartmann L. M. Geschichte Italiens. / L. M. Hartmann. - Bd. I. - Gotha, 1897. - s. 296330; Haury S. Die letzten Ostgothen. / S. Haury. - Monaco, 1915.; Romano G. Le dominazioni barbariche in Italia. / G. Romano, A. Solmi. - Milano, 1940. Часто акцентирует на бытовых этнокультурных противоречиях также и 3. В. Удальцова в своей монографии «Италия и Византия в VI веке». В целом, необходимо подчеркнуть, что попытка «произвести» итальянский этнос из «мировоззренческого столкновения» с греками-византийцами, характерна для всех историко-германистов. Поэтому её необходимо расценивать не столько как признак итальянской национальной исторической школы, сколько как философское наследие германского национализма в итальянской литературе.

130 K началу лангобардского вторжения в Италию (568-572 гг.) прошло всего шестнадцать лет с момента победы Византии (552г.) в противостоянии с остготами.

131 Арабы завоевали грекоязычную Сицилию и часть Южной Италии в 827-840 гг. и контролировали остров и отдельные континентальные районы вплоть до второй половины ХІ века.

132 В 1059-1100 гг. нормандцы завоевали Сицилию и большую часть Южной Италии, заменив собственным герцогством арабское владычество. Основными языками юга Италии в эти годы были греческий, арабский и нормандский. Ни о какой итальянской идентичности еще не могло быть и речи. Центральная Италия, контролируемая папством, также не могла быть оплотом «итальянства». Папство рекрутировало чиновников-наёмников и клириков со всей Европы. Папы создавали тогда совсем другую идентичность - «католическую» (с греческого 
Венеции, Истрии). Вот почему говорить о появлении или активном формировании итальянской этнонациональной идентичности во времена кампаний Юстиниана Великого (527-565) некорректно.

Смена военно-политической принадлежности, часто практиковавшаяся в войне 541-552 гг., не выходила за рамки общепринятого политического процесса133 (тем более, учитывая провинциальный статус Италии в Византии, речь шла о процессе внутриполитическом).

Знатью, командирами, вождями и солдатами руководила, прежде всего, жажда сохранить жизнь и занимаемое экономическое положение. Часто смена политической ориентации позволяла не только сохранить, но и приумножить материальные и нематериальные блага ${ }^{134}$. Тем более, что переход византийцев на сторону врага вовсе не означал отказа от формального подчинения императору. Ведь позже многие византийские дезертиры вернулись под знамена Нарсеса. Они не приносили присягу заново и не считались новобранцами. Они просто меняли политическую ориентацию, но не юридическую принадлежность. Эта тонкая грань хорошо видна в контексте второй итальянской кампании 541-552 годов. Она служит лишним подтверждением правового статуса итальянских событий как гражданской войны.

Итак, война 541-552 гг., по своему правовому положению, была гражданской войной внутри Римской империи, которая развивалась по типичной формуле «преступления и наказания». Сначала был факт неповиновения императорской власти, а затем последовало наказание и применение силы. Нарушение закона повлекло за собой санкцию государственного аппарата.

Несмотря на прокламации Тотилы и некоторые идеологические попытки обосновать «итало-готскую общность», итальянской этнонациональной идентичности не существовало. Был юридический факт - принадлежность к Восточной Римской империи. Был и политический

«кафолическая» переводится как «всеобщая»). К слову, одним из самых выдающихся пап в это время был Григорий VII Гильдебранд (1073-1085), создавший при помощи нормандщев Папскую республику и победивший немецких императоров.

133 Никто не станет спорить с утверждением, что смена идейно-политической или партийной принадлежности отдельных лиц, групп лиц или даже целых народов является обыденной частью политики.

134 И сегодня немногие способны устоять перед естественным человеческим инструментализмом. 
факт - лояльность к восточному императору и осознание единства всего Римского мира. Другое дело - территориальная идентичность. В системе понятий территориальной идентичности скрываются зародыши того, что сегодня принято называть национальным самосознанием. Не будем забывать: влияние географического фактора (месторазвития в терминологии Л. И. Мечникова, П. Н. Савицкого и Г. В. Вернадского) на общественное устройство и социальную психологию народов так велико, что весь исторический процесс в значительной степени является порождением и результатом этого влияния.

И политическая, и этническая идентичности напрямую зависят от «географического ареала» - территории, «месторазвития». К примеру, римская идея призывала народы Средиземноморья к психологическому самоотождествлению с политическими символами и атрибутами Императорского Рима, с величием и широтой его завоеваний. Но этническая история дает нам немало примеров разделенного (даже конфронтационного) проживания этнических групп в рамках одного пространства с присущим им отождествлением своего этнического «я» со всем этим пространством. Точно такой же показательный пример составляет Италия в эпоху ее повторного отвоевания Нарсесом (552 год).

Итальянцы, по праву крови, отождествляли себя со своей землей. Византийцы, по праву императорской власти и согласно с римской идеей, считали Италию своей землей. Остготы же называли Италию своей по праву силы. При этом, во всех трех случаях очень тяжело говорить о наличии какого-либо этнического ядра. Среди итальянцев проживало огромное количество греков, потомков кельтов и германцев. Среди византийцев также встречалось огромное количество людей с итальянским (чаще) или германским (реже) происхождением, а также массы славян, армян, даже гуннов. В среде остготов, на определенных этапах, становился заметным политический вес ругов, герулов. В остготской армии, без сомнения, сохранялись еще потомки племен, прорвавшихся на земли Западной Римской империи 31 декабря 406 г. и оставшихся в Италии после победы Одоакра (476-493 гг.). Поэтому нельзя согласиться с тем, что всего в одном десятилетии (540-550 гг.) были заложены какие-либо противоречия (в частности, этнопсихологические и социально-культурные), составившие в дальнейшем поле для конфронтации между условными Западом и Востоком. Такого закладывания противоречий не было, так как объективные причины цивилизационно-исторического и мировоззренческого характера не могли этого позволить. Сохранялось психологическое главенство «римской идеи». Но самое главное, что 
сохранялась сама Римская империя, которая вступила при императоре Юстиниане Великом (527-565) на вершину своего военно-политического могущества.

Editor-in-Chief Viktor Melnyk (Kyiv, Ukraine)

THE STRUGGLE OF BYZANTIUM FOR THE RIGHT TO OWN ITALY: HISTORICAL AND LEGAL CHARACTERISTICS OF THE WAR IN 541-552 AD

The change of military-political affiliation, often practiced in the war of 541-552 AD, did not go beyond the generally accepted political process (given the provincial status of Italy in Byzantium, it was a domestic political process). The noblemans and soldiers were led, first of all, by a thirst to preserve life and economic position. They did not take the oath again and were not considered recruits. They simply changed their political orientation, but not their legal affiliation. This fine line, analyzed in this article, is clearly visible in the context of the second Italian military campaign of 541-552 AD, which we characterize as the "struggle of the Eastern Roman Empire for the right to own the province of Italy". In any case, the war of 541-552 AD, according to its legal status, was a civil war within the Roman Empire, which developed according to the typical formula of "crime and punishment". At first there was a fact of disobedience to imperial power, and then punishment and the use of force followed. Violation of the law entailed the sanction of the state apparatus. The article refutes the sovereign status of Ostrogoth Italy in the period under review.

Keywords: Eastern Roman Empire (Byzantium), Personal Property of the Emperor, Byzantine Italy, Justinian the Great, King Totila (Baduila), Commander Narses.

главный редактор Виктор Мельник (Киев, Украина)

\section{БОРЬБА ВИЗАНТИИ ЗА ПРАВО ВЛАДЕНИЯ ИТАЛИЕЙ: ИСТОРИКО- ЮРИДИЧЕСКАЯ ХАРАКТЕРИСТИКА ВОЙНЫ 541-552 ГГ.}

Смена военно-политической принадлежности, часто практиковавшаяся в войне 541-552 гг., не выходила за рамки общепринятого политического процесса (учитывая провинциальный статус Италии в Византии, речь шла о процессе внутриполитическом). Знатью и солдатами руководила, прежде всего, жажда сохранить жизнь и занимаемое экономическое положение. Они не приносили присягу заново и не считались новобранцами. Они просто меняли политическую ориентацию, но не юридическую принадлежность. Эта тонкая грань, анализируемая в данной статье, хорошо видна в контексте второй итальянской военной кампании 541-552 гг., которую мы характеризуем как «борьбу Восточной Римской империи за право владения провинцией Италия». В любом случае, война 541-552 гг., по своему правовому положению, была гражданской войной внутри Римской империи, которая развивалась по типичной формуле «преступления и наказания». Сначала был факт неповиновения императорской власти, а затем последовало наказание и применение силы. Нарушение закона повлекло за собой санкцию государственного аппарата. Статья опровергает 
суверенный статус Остготской Италии в рассматриваемый период.

Ключевые слова: Восточная Римская империя (Византия), личная собственность императора, византийская Италия, Юстиниан Великий, король Тотила, полководец Нарсес, правовой статус гражданской войны.

головний редактор Віктор Мельник (Київ, Україна)

\section{БОРОТЬБА ВІЗАНТІЇ ЗА ПРАВО ВОЛОДІННЯ ІТАЛІЕЮ: ІСТОРИКО- ЮРИДИЧНА ХАРАКТЕРИСТИКА ВІЙНИ 541-552 pp.}

Зміна військово-політичної приналежності, що часто практикувалася в війні 541552 рр., не виходила за рамки загальноприйнятого політичного процесу (враховуючи провінційний статус Італії в Візантії, йшлося про процес внутрішньополітичний). Знаттю і солдатами керувала, перш за все, спрага зберегти життя і займане економічне становище. Вони не складали присягу заново i не вважалися новобранцями. Вони просто змінювали політичну орієнтацію, але не юридичну належність. Ця тонка грань, проаналізована в даній статті, добре простежується в контексті другої італійської військової кампанії 541552 рр. Ми характеризуємо ії як «боротьбу Східної Римської імперії за право володіння провінцією Італія». У будь-якому випадку, війна 541-552 рр., за своїм правовим положенням, була громадянською війною всередині Римської імперії, що розвивалася за типовою формулою «злочину і покарання». Спочатку був факт непокори імператорській владі, а потім настав час покарання і застосування сили. Порушення закону спричинило за собою санкцію державного апарату.

Ключові слова: Східна Римська імперія (Візантія), особиста власність імператора, візантійська Італія, Юстиніан Великий, король Тотила, полководець Нарсес.

* Мельник Виктор Мирославович - главный редактор научного журнала «Анналы юридической истории», ассистент кафедры политологии философского факультета Киевского национального университета имени Тараса Шевченко, ученый секретарь Международного центра гражданской политологии при КНУ им. Тараса Шевченко, преподаватель кафедры философии и общественных наук Винницкого национального медицинского университета имени Н. И. Пирогова, член American Society for Legal History, член Национального союза журналистов Украины, член Международного союза журналистов (IFG). E-mail: melnyk1996ethnology@gmail.com. 